\title{
Reciprocity in International Affairs: An Analysis of Nigeria/South Africa "Yellow Fever" Diplomatic Face-Off, March, 2012
}

\author{
Egwemi, Victor \\ Department of Political Science, \\ Ibb University, Lapai \\ E-mail: vegwemi@gmail.com \\ 08062908766/08084220830 \\ \& \\ Ochim, Fidelis Ikaade \\ Department of Political Science \\ Federal University, Lafia \\ Nassarawa State, Nigeria
}

\begin{abstract}
This paper analysed the March 2012 yellow fever diplomatic row between Nigeria and South Africa. It argued that the principle of reciprocity in international relations came to the fore in the row. The paper made the point that the row was a mild explosion of underlying tensions between the two African giants. An issue is the quest to be the leader of Africa. Nigeria played this leadership role until the emergence of South Africa from apartheid. The two countries seem capable in terms of the elements of power to confront themselves for Africa's leadership. However, the paper was of strong opinion that a cooperative relationship between the two countries is better than an adversarial
\end{abstract}


one. It argued that the 2012 row may have been better handled by both counties if some restraints were applied. The paper recommended among other things that the two countries need to cooperate more for their own sakes and for the sake of the African continent.

Key Words: Reciprocity, International, Affairs, Diplomatic face-off, Nigeria, South Africa.

\section{Introduction}

In an increasingly globalizing world, relations between countries are a must. After all since no man is an island, it stands to reason that no country can be an island. Counties have different reasons for interacting with one another in the international system. Such interactions could be on the basis of trade, cultural ties, political affiliations and the like. Whatever, the reasons for these contacts, an abiding principle for them is reciprocity. The principle of reciprocity entails that each country expects to be treated in the manner in which it treats others and vice versa. Reciprocity also referred to as retaliation is often used in international relations as a deliberate strategy to end, maintain or nourish diplomatic ties (Obijiofor, 2012b). It has been argued that,

Reciprocity is an indispensable tool of modern foreign relations. It is one of the constant factors in the pursuit of national interest: reciprocity is the practice of making appropriate return for a benefit or harm received from another state (Ibrahim, 2010, p. 57).

The long and short about reciprocity as a principle of interaction between sovereign states is that favours, benefit or penalties that are granted by one state to the citizens or legal entities of another, should be returned in kind (see Odock, 2010). Reciprocity covers issues relating to trade access (or restrictions), copyrights and intellectual property, enforcement of judgments, travel and visa requirements and extradition, among others (Omede \& Aremu, 2013).

This age long principle came to play on the African continent in March 2012 when Nigeria reciprocated South Africa's deportation of 125 of her citizens allegedly on the grounds of possession of fake yellow fever vaccination cards. Nigeria reciprocated by deporting 85 South Africans allegedly for possession of irregular travel documents. These actions and the diplomatic row that followed them may be regarded as a mild explosion in a relationship that can at best be characterized as uneasy.

This paper examines the 2012 yellow fever vaccination card/deportation row between Nigeria and South Africa. However, in order to make sense out of this recent event, the paper examines the relationship between the two Africa nations from a historical perspective. The paper is divided into six parts. After this introduction, section two specifies the theoretical framework used in the analysis. Section three examines Nigeria/South Africa relations up to the recent diplomatic row. Section four 
examines Nigeria's leadership role in Africa and South Africa's threat or challenge to it, while section five examines the implications of the diplomatic face-off. Section six is the concluding part of the paper.

\section{Politics and Power in International Relations}

Politics is the "pursuit and exercise of power" (Sterling, 1974, p. 32). Generally speaking, "politics is inseparable from power" (Sterling, 1974, p. 25). Politics is the process by which power is acquired, maintained and increased. It is the art of "influencing, manipulating or controlling major groups so as to advance the purpose of some against the opposition of others" (Chandra, 1975, p. 5). International politics is not free from this concern with power that dominates domestic politics. In fact, as Hans Morgenthau has noted "international politics like all politics is the struggle for power" (Sterling, 1974, p. 33).

Elsewhere, it has been argued that if politics is the process by which power is acquired, maintained and increased, it is more so in international politics given the seemingly anarchical and often conflictual nature of the international political system. Each nation tries to outdo the other in its quest for power. As a result, power may not only be acquired, maintained and increased, it may indeed be acquired, abused and even lost (Egwemi, 2008; 1998). We will elaborate on this in the next section. Power may be conceived as the ability to control others and may be enhanced by the possession and skillful application of certain elements of power. The elements of power are also sometimes called the determinants of power and they may be divided into three categories; natural, social and ideational. Some scholars classify these elements in terms of stable and unstable, tangible and intangible components (see Chandra, 1975; Egwemi, 1998; 2008).

In evaluating a nations power one should note that power is relative and situational. Power is subject to continuous change. It is wrong to attribute a decisive role to one element to the neglect of others. We must avoid "single factor determinism" as no single factor is absolute even though all factors are not of equal importance. It is important to note that;

The continuing greatness of a country depends upon its ability to adjust its institutions, revise its policy and reformulate its ideas in the light of new tasks and changes... power relationship should not be viewed as static, one time, and one directional relationship. It should be viewed, rather, as a dynamic ongoing and feedback relationship (Chandra, 1975, p. 75).

The present study would be best appreciated if we look at it within the power framework. Generally speaking, "the proposition that power is and ought to be the central concern of international relations provokes few dissenting voices" (Sterling 
1974, p. 36). In the context of international politics, power is the "ability of a state to control the behavior of other states in accordance with its own will" (Sterling, 1974). The theory contends "that behavior in the international system can be explained exclusively or at least essentially in terms of a struggle for power" (Sterling, 1975, p. 36). When Nigeria's relations with South Africa is understood in terms of a struggle for power then the face off over yellow fever cards begins to make more sense. The incidence should not be looked at in isolation but should be regarded as a continuation of the struggle for power on the African continent. Nigeria had prided itself as the leader of Africa until the emergence of South Africa as an independent nation. South Africa seems be interested in leading Africa also and this has manifested in certain levels of animosity and confrontation between the two countries. The yellow fever row is best understood in this context.

\section{A Critique of the Power Framework}

The power framework is criticized as seeing power solely as an end in itself. For these scholars, the criticism if properly considered may not be wholly correct. Without the struggle for power (taken here as national interest, influence and prestige) interaction in the international system as we have it today, will cease to make sense. Even if it is conceded that power is not an end in itself, then power becomes the means to acquiring influence and prestige which boils down to the same thing since influence and prestige are but manifestations of power.

The argument that states may sometimes act for some other reasons not connected with national interest is simplistic since it is inconceivable that states will be motivated most of the time by concern for others, that is, selfless or altruistic motives. In fact it has been forcefully argued that; "self interest is not only a legitimate, but a fundamental cause for national policy... it is in vain to expect government to act continuously on any other grounds than national interest... they have no right to do so being agents not principals" (Chandra, 1975, p. 82).

Finally, the theory is criticized as concentrating on "what is" ignoring "what ought to be" and "what is becoming" and is as such static. This is true only to the extent that it refers to the concept - power - and not it's every day dynamics in relations between states. National interest (whether economic, socio-political, cultural and military) is dynamic and the desire by each state to satisfy its national interest, is ever burning. The question of "what out to be" thus becomes irrelevant as states are continuously faced with only "what is" - the struggle for power (Egwemi, 1998; 2008). In Nigeria's relations with South Africa the issue of how the latter is supposed to relate with the former as its erstwhile benefactor is completely irrelevant and just sentimental. The two countries are faced with the reality of protecting and promoting their national interest! In doing so, even if South Africa seems ungrateful, she is only doing so in 
pursuit of her national interest. Nigeria will do well to look out for her own interest instead of expecting South Africa to be nice to her.

\section{Nigeria-South Africa Relations}

Nigeria's relationship with South Africa has historically vacillated between hostility and cordiality. This pattern of relationship is traceable to the history of the two Sub-Saharan African giants. Historically, Nigeria was one of the leading African State that stood by black South Africans during the struggle against the apartheid regime. She committed a lot of resources to the African National Congress (ANC) in its struggle against apartheid. This gesture was aimed at ensuring that apartheid was liquidated as shall be seen later.

The position adopted at that time by Nigeria stemmed from one of her foreign policy principles. Among other things, one of Nigeria's foreign policy objectives was commitment to ending colonial and minority rule in Africa (Okpaku et al 1991). This burning desire for freedom for all of Africa saw Nigeria committing enormous resources to fighting the apartheid (white minority) regime in South Africa. This led ultimately to the collapse of apartheid in 1990 and saw the emergence of Nelson Mandela of the African National Congress (ANC) as first black president in 1994. It will be recalled that Mandela was imprisoned for 27 years for his fight against the apartheid regime.

Nigeria's brotherhood and good neighborliness has never wavered in all of Africa. This is one of the things that earned her the appellation "The giant of Africa". Nigerian leaders most time have gone extra length to ensure the country helped to solve African's problems even at the expense of the needs of her citizens. For example, Nigeria's leading role in ECOMOG in Liberia and Sierra-Leone, to mention but two cases on the continent showed her commitment to the African continent.

Nigeria's relation with South Africa was adversarial until the end of apartheid. After the collapse of apartheid, Nigeria had relatively friendly relations with South Africa until the regime of the late General Sani Abacha. The regime of Abacha came to power in a season of a global clamor for democracy. In Nigeria this followed the annulment of the June 12, 1993 presidential election in the country by the General Ibrahim Babangida led junta. The end of apartheid and the emergence of Mandela also coincided with this period. Things came to a head in the relationship between the two countries with the execution of Ken Saro Wiwa, the Ogoni environmental and human rights activitist and writer. Saro Wiwa's execution on Friday, November 10, 1995 in spite of the clamor by the Commonwealth of Nations and the United States of America among other calls for clemency generated frayed nerves between Nigeria and South Africa governments during the presidency of Nelson Mandela. In fact as a consequence of the execution of Saro Wiwa, South Africa championed the suspension of Nigeria from the Commonwealth. This issue further led to diplomatic wrangles between the 
two countries and indeed led to South Africa not only severing diplomatic relations with Nigeria but pressing for sanctions against her as captured by Umunna in a feature in The Week magazine of that period as follows. According to Umunna (1995) "by the last count before we went to press, not less than 20 countries have recalled their ambassadors, some of these countries notably South Africa, the United States and Britain are pressing for harsher sanctions against Nigeria..." (p. 3).

The sour relations continued until Nigeria's return to civil rule in 1999 under the leadership of President Olusegun Obasanjo, and the subsequent election of Thabo Mbeki as the new helmsman of South Africa. Following the election of these two leaders, the relations were normalized and diplomatic relations became cordial again.

Such cordial relations manifested in Nigeria and South Africa playing leading roles in canvassing for the establishment of the New Partnership for Africa development (NEPAD) in 2000. This initiative was widely touted as a homegrown development strategy even when NEPAD went cap in hand begging for funding from the G8 meeting in Genoa, Italy of the same year (Asobie, 2000). Away from that, Nigeria-South Africa bi-lateral relations led to the establishment of the bi-National Commission in 1999. This commission is to facilitate the efficient management of relations between the two countries. (Ngwenya, SAIIA, 2010).

The economic ties between the two countries can be gleaned from the presence of MTN, a South African company and the largest telecommunications service provider in Nigeria with over 42 million subscribers out of the 95 million total active subscribers in the country (Odoh et'al, 2012:5: Ngwenya, SAIIA, 2010). Others include StanbicIBTC Bank, and other major South African blue chips companies operating in Nigeria such as Eskom that executes projects for Power Holding Company of Nigeria (PHCN) and PetroSA, the state owned oil company which has formed a partnership with Monipulo Nigeria and already prospecting and exploring oil in Nigeria (Okereocha, 2012; Ngwenya, SAIIA 2010).

On the other hand, Nigeria has interests in trade with companies like Oando and Dangote group making incursions into Johannesburg Securities and Exchange Commission (Ngwenya 2010). Others include Nigerians having retail outlets and restaurants across the rainbow country.

\section{Nigeria's Leadership Role in Africa}

The title giant of Africa borne by Nigeria may not be just literal after all. Nigeria has earned the title out of her enormous and unparalleled commitment to the African cause from the North to the South, and from the East to the West of the continent. Nigeria has done this by committing her human and material resources in her quest for good neighborliness and brotherhood in peace keeping, peace building, and peace enforcement in Africa, direct giving of handouts, troubleshooting and her 
role in the liberation of South Africa from the white minority apartheid regime in 1990, to mention but a few.

Nigeria's commitment may be elaborated with examples. In 1960, then a newly independent nation state from Britain, Nigeria contributed troops to the Congo crisis of 1960 (Dokubo, 2005). It would be recalled that the Congo crisis erupted during the cold war era. The mineral rich Congo was divided into two camps. The former Soviet Union supported the radical Premier Patrice Lumumba and USA supported the moderate President Joseph Kasavubu. This culminated in the death of Lumumba as accounted for by Dokubo as follows"... Washington's central intelligence agency (CIA) was allegedly involved in the assassination of Lumumba in 1961" (Dokubo 2005, p. 260).

He continues as follows,"... without the support of Nigeria, the most populous state in black Africa, the UN secretary General, Dag Hmmarskjold would have found it very difficult to carry on after the withdrawal of the troops of the Casablanca Bloc States as a result of the death of Mr. Patrice Lumumba in 1961" (Dokubo 2005, p. 261).

Relentlessly, Nigeria has engaged in both bi-lateral and continental peace keeping missions apart from the UN sponsored missions in Africa and even beyond. It would be recalled that Nigerian soldiers went to Tanzania to help maintain law and order following a mutiny in the Tanganikan Army (Dokubo 2005). An account of this is rendered by Nwolise thus,

...a mutiny of military men occurred in Tanganyika (now Tanzania); and Nigeria was requested to send troops by the government of Julius Nyerere to help restore and maintain peace, law and order. Nigerian troops also assisted in training Tanzanian military forces before returning (Nwolise 2004, p. 56).

Also, in 1979, Nigeria convened a conference in Kano to reconcile the main factions in the Chadian crisis. It would be recalled that in 1978, the former Chadian President Felix Malloum sought Nigeria's assistance to that effect (Dokubo 2005). The Nigerian government provided a peace keeping force to monitor the ceasefire agreement and also guarantee the safety of the people of N'djamena, the country's capital (Dokubu 2005).

Under the former military President, General Ibrahim Badamasi Babangida in 1990, under the umbrella of ECOWAS, the ECOWAS Ceasefire monitoring Group (ECOMOG) was formed and funded majorly by Nigeria. The Liberian civil war waged by the then rebel leader Charles Taylor against then President Samuel Doe would have ravaged the country for a much longer period if not for the intervention of ECOMOG. What started as a minor skirmish assumed the status of a full blown civil war. As Nwolise succinctly puts it; 
The Liberian war was initially fought at a very low scale. It stated as a minor skirmish with Charles Taylor's forces attacking border posts in Liberia. While President Doe had his National Army, Mr. Taylor had his guerrilla fighters, all of a few thousand soldiers... things quickly changed as Doe soon found that the rebels were determined to oust his government. He thus recruited unemployed youths (mainly khran), released Political prisoners to boost the size of his 6,000 Armed Forces of Liberia, while Taylor too recruited over 10,000 men who were paid better salaries (Nwolise 1992, p. 56).

Soon as can be deciphered from the above, the war snowballed into a tribal affair as the Gio and Mano ethnic groups were marked for elimination by Doe's forces, while Taylor's forces marked out the Khran people for destruction. From that point the killings and kidnappings became uncontrollable and spread to refugees and even foreigners (Nwolise, 1992).

The above was what informed and led to the establishment of ECOMOG by ECOWAS and saw Nigeria spending tens of thousands of US dollars as pointed out by Nwolise (2004). In fact, it has been said that Nigeria spent about one billion naira daily in Liberia alone. On the whole in the Liberian cause, a number of Nigerians lost their lives; others were maimed or disabled, all in Nigeria's quest for Africa's cause. Charles Taylor, rebel leader of National Patriotic Front of Liberia had made it a point to deal with Nigerian citizens in that period as Nwolise (1992) recalls; "the citizens of Nigeria, Ghana, Sierra-Leone and Guinea were specifically marked for elimination. In short, Mr. Taylor vowed to kill a Nigerian or Ghanaian for each Liberian killed by ECOMOG forces" (p.59).

It is on record that in Liberia alone, ECOMOG lost over 500 soldiers, and... "Nigeria suffered 80\% of the losses from official statements" (Nwolise 1992:58). The Nigerian Press was not spared as "Kriss Imodibe of The Guardian and Tayo Awotosin of the Daily Champion... disappeared, with rebel sources hinting that they have been killed as spies" (Nwolise 1992, p. 58).

The refugee's crisis arising from the development saw Nigeria shouldering a further commitment as Nigeria was reported to have "hosted over 141,000 out of the over 600,000 Liberian refugees" (Nwolise 1992, p. 59). Apart from the above, Nigerians living in Liberia were humiliated, maimed and even killed. Thus, Nigeria's commitment to Africa's is indeed unparalleled and is not subject to comparison.

The Liberian war affected its neighbor Sierra Leone negatively. This again saw ECOMOG engage in peace keeping and later peace enforcement in Sierra Leone. This was accounted by Dokubo thus; 
The Sierra Leone conflict commenced in March 1991, when the Revolutionary United Front (RUF) under Foday Sankoh launched a series of attacks to overthrow the government of Joseph Momoh. In February 1998, responding to an attack by the junta forces, ECOMOG launched a military attack, which led to the collapse of the junta... and on March 10, 1998, President Kabbah was returned to office (Dokubo, 2005, p. 260).

The above was a plus to ECOMOG, and no less to Nigeria. As earlier pointed out, Nigeria played a pivotal role in bringing the apartheid regime in South Africa its knees. This led to Nelson Mandela emerging as the first Black President in 1994.

During the Olusegun Obasanjo civilian presidency, and in line with Nigeria's foreign policy objectives, and in his capacity as the Chairman of the African Union, President Obasanjo had engaged in peace building... in Sao Tome and principle, where he was successful in persuading dissident soldiers to subject themselves to constituted authority (Dokubo 2005).

Not only that, President Obasanjo also used his good office to broker peace talks in Abuja towards solving the conflict in Darfur, Western Sudan. Nigeria also, contributed 150 peace keepers to provide protection for refugees and UN workers. In Rwanda, Nigeria provided 150 peace keepers. This number was to be progressively increased depending on the situation on ground and need (Dokubo, 2005). Nigeria also strongly influenced the transformation of the organization of Africa Unity (OAU) to Africa Union (AU). As clearly seen above, Nigeria's commitment to fellow African states has been enormous beginning from independence to date. This cannot be over flogged or emphasized. The foregoing discussion is without prejudice to South Africa's right to aspire to a leadership role in Africa.

\section{International Rules of Aviation and the Yellow Fever Saga}

Crises-crossing the international air space, there are rules and regulations guiding travelers and operators of air travel companies. Accordingly, there are health check officials, security officials and immigration officials among other authorities at airports across the world. This is to ensure that travel documents are up to date and that none of the rules of international travel is breached. The March, 2012 yellow fever vaccination card crises between South Africa and Nigeria brewed because of the allegations leveled against 125 Nigerians whose yellow fever certificates were alleged to be fake (Daily Trust, March 7, 2012:5). This led to the deportation of the said 125 Nigerians.

The International Health Regulations (IHR) issued by the World Health Organization, 2005, section 32, provides that; travelers from countries at risk of yellow 
fever ... show an international certificate of vaccination against yellow fever which is in turn required to procure travel visas (in Odoh et al, 2012, p. 5)

The above provision is the reason why the then Nigerian Health Minister, Professor Onyebuchi Chukwu, was at a loss over the deportation of the 125 Nigerians. In his words;

It is obviously very curious that a country that has issued entry visas to intending travelers, whose issuance is predicated on the presentation of a valid yellow fever card, would then turn around at the point of entry to deport those travelers (in Odoh et al, 2012, p. 5).

But is Nigeria classified as a yellow fever prevalent country? Professor Chukwu's answer was that: "Nigeria had no yellow fever prevalence and as such its citizens should not have been subjected to such an action from the South African government" (Odoh et al, 2012, p. 5).

However in spite of this, there are some countries that require that Nigerians produce their vaccination cards against yellow fever before entering their countries. These countries the Health Minister mentioned to include South Africa, Zimbabwe, India and Saudi Arabia. On the part of Nigeria, it is required that travelers coming into the country from yellow fever at-risk countries produce evidence of vaccination against yellow fever in accordance with the IHR 2005 (in Odoh et al, 2012, p.5).

In all of this there is a crucial question; were there other ways South African authorities could have remedied the situation apart from outright deportation? Nigeria's former Ambassador to Sudan, and former representative at the United Nations, Ambassador Suleiman Dahiru renders the following opinion:

Every country has its own rules and regulations and not just a question of having visa...if Nigerians went there without, the cards, or if the cards were discovered to be fake, South Africa is perfectly right to take such action. (Odoh et al, 2012, p. 5).

And from his personal experience when he was in Pakistan, Dahiru recalls that a Deputy Governor of a state went to the country without the card and he was quarantined (Odoh et al, 2012).

Could the 125 Nigerians have been quarantined? And are there any unanswered questions on this issue? Did South Africa act in error? Was it a calculated attempt to drag Nigeria's name into disrepute in the eyes of the world? Or was it cold diplomacy in action? Did the Nigerian travelers indeed flout the yellow fever rules or did they play a fast one on the South African High Commission's travel document officers? And if then, and in all of these, how then did the Nigerian travelers get their 
visas for which yellow fever certificates is a pre-condition? There are indeed so many questions begging for answers.

Thus, it is imperative to undertake a proper examination of the issues at stake. It should not be seen only in terms of reciprocity, of Nigeria "sending back over 100 South Africa entering the country" (Okereocha, 2012, p. 28). It is not even the immediate value of resolving the crisis fast that matters, but, most importantly there must be serious attempts at articulating the reasons that led to the deportation in the first place. It also requires Nigerian government to have a re-assessment of her domestic policies and administration of citizenship, to see where she is getting it right or wrong.

\section{South Africa and Nigeria: Flexing of Diplomatic Muscles}

The diplomatic face-off between Nigeria and South Africa over the latter's deportation of 125 Nigerians on March 1, 2012, seems to have fizzled out but there is an important need to understand the motive behind the action in the first place. One main reason that may be adduced is xenophobia. South Africa's xenophobic attitude towards Nigerians and indeed other Africans is not new. (Obijofor, 2012a; Aidelokhai and Musa, 2011). Perhaps it is Nigeria's reaction to this out of the many incidences of unfair treatment meted to her citizens by South Africans that is new (Kayode, 2012). This attitude towards Nigerians in South Africa according to Kayode dates back to year 2000. Complaints have been lodged to the South African high commission, but to no avail. (Kayode, 2012).

Be that as it may, beyond xenophobia, South Africa may be up to more than meets the eye. The NIIA Director General, Professor Akinterinwa has provided the following insight;

A school of thought holds that the deportation of 125 Nigerians is merely a symptom of a bigger problem; the main issue which is the objective of South Africa in Africa, is yet to be addressed, Deporting people is just a manifestation of the objective (in Okereocha, 2012, p. 28).

Professor Akinterinwa argues further that the objective of South Africa is twofold. The first one is to be the leading nation in Africa. This is signaled in South Africa's interest in the re-location of the Headquarters of the African Union (AU), and thus;

South Africa has adopted the cheque book diplomacy which entails settling the debts of some African countries unable to pay their dues to the AU in order to guarantee political support in all the five regions of Africa (Okereocha, 2012, p. 28). 
This to the eminent scholar is flouting one of the rules or principles of the AU which;

Allows each region in Africa to find solutions to its problems, but where there is difficulty, the region could come back to the continental organization where the matter is taken up and discussed meaningfully (in Okereocha, 2012, p. 29)

To this end, the argument is that, South Africa; in her quest to lead Africa has not been respecting the rules as laid down in the AU's law book. But more importantly, underneath the "cheque book diplomacy" lies South Africa's quest to become a permanent member of the United Nations Security Council. As akinterinwa asserts;

South Africa is contesting the position with Nigeria... even though the UN and the whole world have acknowledge Nigeria's contributions of soldiers to UN peace keeping missions in Africa, large population and abundant human and natural resources, especially oil, South Africa has since launched a campaign to become the only African nation with a permanent seat on the UN security Council (in Okereocha, 2012, p. 29).

Other reasons underneath the deportation saga on the side of South Africa include, the failure of Nigeria to back South Africa's bid to install Nkosazena DlaminiZuma its Home Affair Minister, as the new Chairperson of the AU Commission (Okereocha, 2012).

The above are pointers to South Africa's continental aspirations. To pay back and in the spirit of reciprocity, South Africa opposed the idea backed by Nigeria for the establishment of the Central Bank of Africa in terms of which the AU would take over the responsibilities of an African Monetary Fund and establish a single currency by 2028 (Okereocha, 2012). Thus, the battle of wits may have just begun as to who dominates Africa's leadership and politics. It is still too early in the day to determine who will eventually win. What is important at this point is that the two combatants are very capable indeed.

One argument which the Nigerian government and people have harped upon in the relationship with South Africa is that the latter needs to continually show appreciation to the former for the role it played in its liberation struggle. This argument is neither here nor there. In fact it is a stale argument which runs against the grain of the conduct of relations between countries in the international political system (Adamu, 2012: Egwemi, 2008). Elsewhere it has been argued concerning Nigeria's relations with post apartheid South African and in the face of every nations quest to safe guard its national interest that; 
If Nigeria concentrates on "what ought to be", that South Africa owes her for her role in the dismantling of apartheid then she will continue to miss the point. All countries are faced with "what is" in the struggle for power.....South Africa is concerned only with its own self interest... even if south Africa makes diplomatic gains at the expense of Nigeria; she is only following the only rule in the conduct of relations between countries...(Egwemi, 2008:106).

It has to be understood clearly that self interest is the major driver of a nation's foreign policy actions. To expect South Africa to continuously relate with Nigeria on the basis of past benevolence is misleading. South Africa can only look out for its own interest irrespective of the expectations of Nigerians. After all, the so-called help in the past earned Nigeria some intangible gains in terms of the raising of her international prestige (Adibe, 2011). Furthermore as Adibe has argued, it would seem that after Nigeria helps these (African) countries, the population of Nigerians in them increases as Nigerian human capital is unleashed on them. Nigeria in his opinion while focusing on the ingratitude of these countries conveniently forgets the contributions of Nigerians to her economy via remittances (Adibe, 2011). And so it may be the case that Nigeria's help is more than reciprocated even though it is not on terms that Nigeria and Nigerians are able to relate to easily.

And in a manner that completely dismisses Nigeria's so called contribution to South Africa's liberation, Adebayo Lamikanra has made the following matter-of-fact argument and we quote him in extenso;

....it will be hypocritical for any Nigerian to beat his chest and proclaim that we had something more potent than moral support to offer the people of South Africa in their hour of need. To my knowledge, no single Nigerian soldier or civilian lost his life to the hateful apartheid system and that we gave sanctuary to a few South Africans in their hour of need is hardly something we can beat our collective chests about since many more of them found sanctuary in London than in Lagos. It was themselves who were cut down in the street in their thousands, herded into jail in their tens of thousands, herded and faced daily humiliations in their millions, who fought and ultimately won their bitter fight. For any Nigerian to claim credit for the fall of apartheid is to do gratuitous violence to the history of the black people of South Africa (Lamikanra, 2012, p. 50)

\section{Lessons from the Diplomatic Face-off}

There are important lessons to be learned from the face-off between Africa's two giants. These lessons if taken seriously will go a long way to strengthening ties 
between them and if glossed over may further jeopardize relations. However, it is the opinion of this paper that most of the lessons are for Nigeria to learn.

The first lesson is the need for caution in treating foreign nationals at entry/exit points. Clearly the trigger for the face-off under consideration was the treatment meted to Nigerians on an Arik Airways flight to South Africa. It would seem that all avenues were not explored before the Nigerians were sent back. For instance, it could have been possible for the yellow fever vaccinations to have been administered right there at the airport in Johannesburg (Obe, 2012).

Secondly, the South Africa government needs to tackle the challenge of xenophobia which seems to have taken hold of the country and many of her citizens. Many South Africans believe that other Africans coming into their country are there to take their jobs. The African are generally described as Amakwerekwere, a derogatory name for unwanted blacks (Obijiofor, 2012). Considering the sometime violent manifestations of the amakwerekwere mind set, South Africa needs to tackle the challenge of xenophobia headlong (Aidelokhai and Musa, 2011). These are some of the lessons that South Africa needs to learn from the face-off.

The lessons for Nigerians are many. The first is that her image crisis is still a major challenge. Nigeria has since the early 1990's suffered an image crisis. The image crisis in the country has been the function of two things; the country's then undemocratic standing and the fraudulent activities of some of her citizens (Egwemi, 2003; 2007; 2010). It is instructive that the South African officials had doubts about the authenticity of the yellow fever cards issued in Nigeria. The image challenge therefore remains a burden and government needs to rise to the challenge of tackling it. Secondly, the Nigerian government needs to tackle the reasons for her citizens wanting to travel to and remaining in other countries such as South Africa. In addition to the image crises, made worrisome by the fraudulent activities of Nigerians, it is also the case that Nigerian government officials are very corrupt (see Egwemi and Usman, 2010; Egwemi, 2012a; 2012b). In such a setting government revenue that would have been used to improve infrastructure and standard of living is diverted to personal pockets. This in turn has led to an infrastructure and social well being deficit for Nigerians. As a result countries like South Africa where things seem to be working become very attractive to Nigerians (Ojenagbon, 2012; Emewu, 2012; Ajeluorou, 2012).

The Nigerian government needs to make the country more conducive for her citizens to reduce the temptation as it were to travel. The level of infrastructure and social welfare needs to be improved if Nigerians are to be able to resists the temptation to travel. Of course the positions adopted above are without prejudice to Nigerians who may need to go to South Africa for other purposes apart from seeking the good life. 
Another dimension to the face-off for Nigeria is whether she can continue to live up to the kind of behavior exhibited in the yellow fever face-off in future. That is, can Nigeria sustain such defense of her citizen's interest continuously? Given that this disposition is at variance with how Nigeria has always been known to act, Lamikanra is of the opinion that;

It will (therefore) be a rather foolish Nigerian who can now safely assume that like the government of the United States for example, Nigeria will defy hell or high water to defend the individual interest of a Nigerian in need outside the shores of this land, or come to think of in even within the shores of our country (Lamikanra, 2012, p. 50)

Suck skepticism means that the Nigeria government needs to brace up for similar challenges in the future. If this is not so, the face-off with South Africa over the interest of her citizen will end up a one-off thing (Kperogi, 2012).

It would seem that Nigerian government had an upper hand in the row under consideration. This is to the extent that the South Africa government apologized to Nigeria for deporting her citizens (Fadeyi, 2012; Ahmadu, 2012; Ali and Ehikioya 2012; Okereocha, 2012; Adeyemi, 2012). However, Nigeria needs to know that this is only a sort of Pyrrhic victory. South Africa did indeed apologize but in the post-row period it was the Nigerian Vice President who had to travel to South Africa for the $8^{\text {th }}$ session of the Nigeria- South Africa Bi-National Commission. At this meeting the contentious issue that had led to the frosty relationship between the two countries were discussed and attempts were made to resolve them (Obayuwana, 2012; Daily Trust, May 25, 2012). That it was the Nigerian side that had to go to South Africa to do this meant that her victory in the yellow fever row was only superficial. It must be noted also that South Africa had to apologise to Nigeria in order to protect its numerous investments in the country (Okereocha, 2012). The apology is therefore not something to rejoice about on the part of Nigeria because it was a strategic and practical move by South Africa.

On the whole, there is a major lesson for both counties. It must be made clear that confrontation in whatever guise between Nigeria and South Africa is not in the interest of African brotherhood and solidarity. This being more so when the issues are such that could have been resolved amicably (Ojeinagbon, 2012; Obayuwana, 2012).

\section{Conclusion}

In the aftermath of the March, 2012 diplomatic row between Nigeria and South Africa, efforts have been stepped up to strengthen bilateral relations between the two countries. The importance of this cannot be over emphasized. It is the case that Nigeria and South Africa need to collaborate more in their effort to jointly better the lot of Africa. As a result there is need for more genuine collaboration and cooperation than 
antagonism and animosity. The bi-lateral frenzy that followed the diplomatic row needs to be sustained. (Obayuwana, 2012; Daily Trust, May 25, 2015).

Leaders in both Nigeria and South Africa seem to understand the historic links between the two countries. However, this does not seem to be the case among ordinary citizens of the two countries. Both countries need to educate their citizens on this historic relationship in order to foster a healthier and more rewarding relationship between them. Lastly, and on a realistic note, there is no doubt that Nigeria and South Africa are competitors on the African continent. Be that as it may, the competition should be healthy and such that the two countries can benefit from. The resort to pettiness on both sides as witnessed in the yellow fever row will not do the two countries in particular and the African continent in general any good.

\section{References}

Adamu, A. (2012). "Endless talk of favours" in Daily Trust March 23, 63

Aidelokhai, D. I. \& Musa, U. (2011). Resolving xenophobic crisis in South Africa through diplomacy: Nigeria's options for fostering African integration. Lapai International Journal of Management and Social Sciences 4(2), 308-318

Adeyemi, A. (2012). Eating the humble pie. In Tell, March 19, 47-48

Adiba, J. (2011). How not to formulate foreign policy. In Daily Trust August 19, 68

Ahmad, R.W. (2012). South Africa apologizes to Nigeria. In Daily Trust March 9, 1-2

Alli, Y. \& Ehiioya, A. (2012). South Africa sorry. In The Nation March 9, 1-2

Ajeluorou, A. (2012). Woes of Nigerians in South Africa. In The Guardian, March 16, 29

Asobie, H.A. (2000). Redefinng Nigeria's National Interest. Mimeo, University of Nigeria, Nsukka.

Chandra, P. (1975). International politics. Delhi: Vikas Publishing House PVT Ltd.

Daily Trust (2012). World report: Sambo, others in South Africa to mend relations" May 25, 29.

Dokubo, C. (2005). Nigeria's International Peace Keeping and Peace-Building Efforts in Africa (1960-2005). In Akinterinwa, B. (Ed.) (2005). Nigeria and the United Nations Security Council. Ibadan: Vantage Publishers Ltd.

Egwemi, V. (ed.) (2012a). Corruption in Nigeria: Issues, challenges and possibilities. Makurdi: Aboki Publishers. Pp. 285.

(2012b). Corruption and Corrupt Practice in Nigeria: An Agenda for Taming the Monster. Journal of Sustainable Development in Africa 14(3), 72-85. 
------ (2010). Managing Nigeria's image Crisis: Akunyili's Rebranding Progamme to the Rescue. Current Research Journal of Economic Theory 2(3), 131 - 135.

(2008). The place of power in the relationship between states: Some comments on Nigeria/South Africa Relations" in knowledge Review 16(4), 100 - 107

------- (2007). June 121993 and Nigeria's Image cries. Journal of Social and Policy Issues 4 (4) 11-15

(2003). Image crises and Nigeria's foreign policy: An appraisal of President Obasanjo's diplomatic shuttles. Journal of Economic and Management Studies 1 (1) $170-177$

(1998). The annulment of the June 12, 1993 Presidential election and its impact on Nigeria's leadership role in Africa. Unpublished M.Sc Thesis, ABU Zaria.

Egwemi, V. \& Usman, S.O. (2010). Corruption and corrupt practices in Nigeria: Manifestations and consequences. Kogi State University Bi-Annual Journal of Public Law 3 (1), 105 - 111.

Emewu, I. (2012). Nigeria, South Africa's new colonial territory. Saturday Sun March $10,63$.

Fadeyi, R. (2010). When South Africa's envoy came to apologise. National Mirror March 20, 16

Ibrahim, M. K. (2010). Nigeria-Libya Relations: Reciprocity as a tool of Foreign Policy. Eze, O.C. (Ed.) Reciprocity in international relations. Lagos: Nigerian Institute of International Affairs 57 - 66.

Kperogi, F. (2012). Nigeria's new diplomacy of reciprocal deportation. Weekly Trust March 17, 38.

Lamikanra, A. (2012). South Africa - Nigeria Feud: Yellow Diplomacy. The Guardian, March, 18, 50.

Ngwenya, X. (2010). Giants of Africa limp along -South Africa and Nigeria (www.saiia.sa.gov) retrieved on 24 June 2012.

Nwolise, O. B.C (2004). The Nigeria police in international peace-keeping under the United Nations Ibadan: Spectrum Books Ltd

Nwolise, O.B.C (1992). The Internationalization of the Liberian Crisis and its effects on West Africa. In Vogt, M. A. (1992). The Liberian crisis and ECOMOG: A bold attempt at regional peace keeping Lagos: Gabumo Publishing Cc. Ltd. 
Obayuwana, O. (2012). Nigeria, South Africa Relations enter a new dawn. In The Guardian June 19, 17

Obe, A. (2012). Nigeria, South Africa: getting petty. The Guardian, March 14, 51.

Obijiofor, L. (2012a). South Africa must fight xenophobia. The Guardian March, 9, 51

Obijiofor, L. (2012b). Go ye forth and retaliate. The Guardian March, 16, 51

Odock, C. N. (2010). Nigeria-France relations: Dominance, reciprocity or identity. In Eze, O.C. (ed) Reciprocity in international relations. Lagos: Nigeria Institute of International Affairs 133-162.

Odoh, A. et'al (2012). Nigeria-South Africa standoff deepens. Daily Trust March 26, $28-30$.

Ojeinagbon, P. (2012). Lessons from Nigeria-South Africa Feud. The Guardian March, 19,68 .

Okereocha, C. (2012). Nigeria-South Africa diplomatic row: The morning after. Tell March 26, 28 -30.

Okpaku, O. J. et al (1991). Nigeria at the United Nations Abuja: Ministry of External Affairs, Federal, Republic of Nigeria.

Omede, A. J. \& Aremu, F. A. (2013). Basic Concepts in International Relations. In Saliu, H. A. \& Aremu, F. A. (eds.) Introduction to international relations. Ibadan: College Press and Publishers Limited 29-44.

Sterling, R.W. (1974). Macropolitics: International politics in a global society. New York: Alfred Knopf.

Umunna, I. (1995). The last testament. The Week November 27, 10 - 15. 